\title{
Filmowiec nie może działać wyłącznie lokalnie. Z Krzysztofem Zanussim o współpracy z kinematografia niemiecka rozmawia Ewa Ciszewska
}

\author{
KRZYSZTOF ZANUSSI \\ EWA CISZEWSKA \\ Katedra Mediów i Kultury Audiowizualnej \\ Uniwersytet Łódzki
}

\begin{abstract}
Aвstract. Filmowiec nie może działać wyłacznie lokalnie. Z Krzysztofem Zanussim o współpracy z kinematografia niemiecka rozmawia Ewa Ciszewska [A true filmmaker cannot work only in his homeland. A conversation with Krzysztof Zanussi about his co-operation with the German film industry by Ewa Ciszewska]. „Images” vol. XXIII, no. 32. Poznań 2018. Adam Mickiewicz University Press. Pp. 177-184. ISSN 1731-450X. DOI 10.14746/i.2018.32.14

The paper presents an interview with Krzysztof Zanussi (born 17 June 1939), one of the most renowned award-winning Polish film directors. Some of his numerous films for television and cinema have been made in co-operation with German producers, including Manfred Durniok. His film Roads in the Night (Wege in der Nacht, 1979) was presented in 1980 in Cannes as part of the section "Un certain regard". In Germany, Zanussi filmed not only some of his own screenplays, such as Imperative (Imperativ, 1982 - Special Jury Prize at the Venice International Film Festival in 1982), but also adaptations of Polish and German literature, for example House of Women (Haus der Frauen, 1977) based on a play by Zofia Nałkowska and Bluebeard (Blaubart, 1983) based on a novel by Max Frisch. In addition to those productions, he concurrently made films in Poland. Director of the TOR Film Studio since 1979. He produced films by such directors as Krzysztof Kieślowski and Agnieszka Holland. He currently works on a feature film entitled Ether.
\end{abstract}

KEYwORDs: cultural transfer, Krzysztof Zanussi, co-productions, Germany, Poland, GDR, FRG

EWA CISZEWSKA (E.C.): Swoją karierę reżysera rozpoczynał Pan w czasach kiedy podejmowanie współpracy $\mathrm{z}$ zagranicznymi producentami, angażowanie międzynarodowej obsady, szukanie środków na filmy poza granicami Polski nie było powszechną praktyką. Dziś wydaje się to czymś oczywistym i pożądanym, ale w latach siedemdziesiątych można było kręcić filmy w ramach polskiej kinematografii, nie wychodząc poza jej ramy. Pan wybrał inną drogę.

KRZYSZTOF ZANUSSI (K.Z.): Europa jest polem, na którym trzeba być obecnym, nie można działać wyłącznie lokalnie. Miałem taką prostą psychologiczną motywację - chciałem zobaczyć, czy to, co umiem, sprawdzi się gdzieś indziej. Zadawałem sobie pytanie, czy jesteśmy coś warci tam, gdzie nie mamy punktów dodatkowych za narodowość. Wśród artystów taka motywacja jest dość powszechna - dlaczego pianiści wyjeżdżają za granicę, skoro mogliby wszyscy grać w kraju? A jednak wyjeżdżają, bo tak ich to pociąga. Filmowiec jest w mniej korzystnej sytuacji, ponieważ operuje sztuką semantyczną. W ogóle wchodzenie w dialog ze światem jest czymś szalenie pociągającym.

E.C.: Z kinematografią niemiecką zrealizował Pan szereg filmów. Były to zarówno produkcje kinowe, jak i telewizyjne. Pracował Pan w projektach "czysto" niemieckich, jak i takich, w których stroną były podmioty $\mathrm{z}$ różnych krajów. Jak doszło do tej współpracy? 
178 VARIA

K.Z.: Niemcy Zachodnie w Polsce były traktowane jako kraj wyjątkowo nieżyczliwy. Rzeczywistość wyglądała inaczej. Niemcy byli bardzo nami zainteresowani, byli bardzo otwarci na współpracę. To raczej nasze władze piętrzyły trudności. Wobec tego bardzo mnie pociągło aby w ten obszar wejść i coś tam zrobić. Pierwsze było Życie rodzinne (1970), to była przedsprzedaż. Pan Manfred Durniok kupił ten film na pniu, więc kręcąc, wiedziałem, że mam ten film sprzedany do Niemiec. Potem były małe, półgodzinne filmy dla ZDF - jak Rola (1971) z Janem Kreczmarem i Danielem Olbrychskim czy Hipoteza (1972), z której, notabene, jestem bardzo zadowolony. Hipoteze robiłem dla ZDF, potem doszła do tego projektu Telewizja Polska - stąd dwie czołówki, które się wykluczają. Formalnie Telewizja Polska nie mogła wówczas pracować z ZDF. Wobec tego jedna czołówka mówi, że to jest film Telewizji Polskiej, w Niemczech funkcjonuje czołówka, która mówi, że jest to film telewizji niemieckiej, nie ma tam słowa o Polakach.

E.C.: Zderzenie mentalności Wschodu i Zachodu było jednym z tematów Pana filmów realizowanych w Niemczech. W 1975 roku zrealizował Pan Miłosierdzie płatne z góry. W historii baronowej, poniżającej i zniewalającej w ciągu jednej nocy Jugosłowiankę dorabiającą jako pielęgniarka, zawarł Pan pełen wachlarz stereotypów o gastarbajterach ze Wschodu.

K.Z.: Obserwacje do tego filmu zbierałem wiele lat. Już jako student, wyjeżdżając za granicę, doświadczałem różnic, które nas dzielą z Zachodem.

E.C.: Wszedł Pan do kinematografii niemieckiej także z projektami typowo polskimi - mam tu na myśli Dom kobiet (1977, Haus der frauen), czyli adaptację polskiej literatury.

K.Z.: Dom kobiet oparty na tekście Zofii Nałkowskiej był świetną okazją do spotkania ze znakomitymi aktorami teatru niemieckiego. Sam zaproponowałem ten tekst - szukałem sztuki, która mogłaby się tam sprawdzić w formacie telewizyjnym. Sztuka była mało rewolucyjna, ale wydawało mi się, że pokazanie Polski ziemiańskiej, inteligenckiej będzie ważne dla nas w Niemczech, że po prostu należy to zrobić.

E.C.: Szybko jednak pojawily się projekty, w których tematyzował Pan relacje polsko-niemieckie, jak Drogi pośród nocy (Wege in der nacht, 1979) o niemożliwej miłości polskiej hrabiny i niemieckiego arystokraty Friedricha. Film ten wielokrotnie pokazywano w programie niemieckiej stacji ARD.

K.Z.: Ten film dał mi poczucie sensu moich działań. Drogi pośród nocy wcześniej nazywały się Preludium deszczowe, ale ówcześni marketingowcy TV powiedzieli, że słowo „preludium” od razu pozbawia nas widzów. Akurat tego tytułu nie lubię, moje pozostałe tytuły są o wiele bardziej pomysłowe. To był film bardzo „od serca”. Wierzyłem, że robię film na ważny temat, który w Niemczech trzeba poruszyć. W filmie pojawia się wątek kultury, która łączy ludzi mimo wojny. Kultury, która zawodzi, bo konflikt narodów ma konsekwencje moralne. Kto godzi się być okupantem, ten nie może być przyjacielem.

E.C.: Zapewne zdarzyły się też projekty niezrealizowane. Którego żałował Pan najbardziej?

K.Z.: Jeden z moich „niemieckich” projektów za długo przeleżał, czego bardzo żałowałem. Mam na myśli film Pokuszenie (Versuchung, 1981). Powinien był powstać dziesięć lat wcześniej, może wtedy byłby żywszy. Ale gdy się pojawiła okazja, trudno mi było powiedzieć „nie”, skoro tak długo o ten film zabiegałem. Ten film był merytorycznie spóźniony i pani Maja Komorowska, odtwórczyni głównej roli, była już o dziesięć lat starsza. Z perspektywy czasu patrzę na te perypetie wokół filmu jako jedną z moich mniej udanych przygód. 
E.C.: Jeden $\mathrm{z}$ Pana projektów ostatecznie wyreżyserował Volker Schlöndorff. Może Pan przybliżyć historię tego przedsięwzięcia?

K.Z.: Kiedy myślę o moich wyborach zawodowych, mam całą listę filmów, które mi się niejako nawinęły i których nie chciałem odmówić, bo nie wolno odmawiać propozycjom, które - jak to mawiamy - „są godne”, choć nie zawsze nam $\mathrm{z}$ nimi po drodze. $\mathrm{W}$ takich okolicznościach zrobiłem film o Janie Pawle II i film według jego sztuki Brat naszego Boga, film o Maksymilianie Kolbem, adaptację tekstów Tankreda Dorsta i Maxa Frischa, a wcześniej mój Catamount Killing, nakręcony całkowicie w Ameryce. A jednego filmu odmówiłem i nie wiem, czy żałować tego, czy się chwalić. W latach dziewięćdziesiątych mój niemiecki producent zaproponował mi scenariusz o luksemburskim księdzu, który trafił do obozu koncentracyjnego w Dachau i został tam zwolniony na dziewięć dni, po to, by powrócił do swojej diecezji i zapoczątkował tam ruch katolików na rzecz współpracy z nazistami. Po dziewięciu dniach rozmów z Gestapo rzeczony ksiądz odmówił i został odesłany do obozu. Kolejny film o okupacji nie był moim marzeniem, przyjąłem jednak tę propozycję pomny na to, że o godną pracę nie jest wcale tak łatwo. Byliśmy już w trakcie preprodukcji, kiedy mój producent przyniósł kilka nowych scen, dopisanych na jego prośbę przez niemieckiego scenarzystę. Sceny te ukazywały, że bohater - więzień Dachau - też był winien, bo kiedy brakło wody, nie podzielił się ze współwięźniami (będąc księdzem). Wątek ten był przepisany z biografii włoskiego pisarza Primo Levi, pochodził z Auschwitz, a nie z Dachau, był historycznie nieprawdziwy i szargał pamięć zmarłego, który był rzeczywistą postacią. Mój producent powiedział mi, że możemy zmienić nazwisko bohatera, ale zależy mu na tym wątku, bo w ten sposób bohater nie będzie bez skazy. Ja zobaczyłem w tym próbę niemieckiej rewizji historii. Jako Polak miałem zaświadczyć, że ofiary też dopuszczały się podłości, więc oprawcy są trochę mniej winni. Zerwałem kontrakt (który był finansowo bardzo atrakcyjny) i do tej pory nie wiem, czy nie byłem nadwrażliwy. Film Dziewięć dni nakręcił w końcu Volker Schlöndorff, wcześnie lojalnie uzgodniwszy ze mną swój udział w tym projekcie.

\section{EC.: W Niemczech zrealizował Pan także esej filmowy Lekcja anatomii (1977).}

K.Z.: To był film ambitny i zaangażowany, lecz dziś za nim nie przepadam. Lekcja anatomii trochę powtarza formułę Iluminacji. Nie udało się jednak powtórzyć tej koncepcji artystycznej w tak udany sposób. Niemniej był to dla mnie film ważny i szalenie niebezpieczny, ponieważ zawierał całą moją wiedzę na temat tego, jak działają tajne służby. Były tam raporty z Amnesty International, które dotyczyły również służb radzieckich.

\section{E.C.: Główną oś fabularną stanowią pery- petie studenta $\mathrm{z}$ Chile.}

K.Z.: Wiodący wątek jest chilijski, ale opisy tortur nie wskazywały, w jakim rejonie świata były wykonywane. Ponad połowa z opisów pochodziła z naszego regionu. Gdy film się ukazał, mój paszport znalazł się pod znakiem zapytania. Jacek Fuksiewicz [krytyk filmowy, od 1972 jako szef Redakcji Produkcji Filmów TVP wspierał rodzące się pokolenie kina moralnego niepokoju przyp. E.C.] doradził Maciejowi Szczepańskiemu [w latach 1972-1980 przewodniczący Komitetu ds. Radia i Telewizji - dop. E.C.], żeby zamiast robić awanturę i stracić Zanussiego, lepiej przekuć to we własny sukces. Szczepański posłuchał tej rady, a film pokazała po północy TVP.

\section{E.C.: Innym ważnym filmem zrealizowa- nym za granicą był Sinobrody (1983) na podstawie Maxa Frischa. Możliwość ad- aptacji docenianego pisarza to chyba było duże wyróżnienie. Droga do sfilmowania utworu była trudna, ponieważ Frisch spe- cjalizował się w zwodzeniu producentów i reżyserów.}

K.Z.: Zdziwiłem się, że zaproponowano mi adaptację literatury niemieckiej, tekst uznanego 
180

VARIA

pisarza. Do tej pory robiłem przecież wyłącznie teksty autorskie. Kiedy zapytałem niemieckich redaktorów telewizyjnych, czy proponują mi tekst Frischa dlatego, że nakręciłem film biograficzny o papieżu, nie zaprzeczyli. Uważali, że osiągnąłem kompromis między wymaganiami amerykańskich finansistów, którzy lokowali w tym projekcie kilka milionów dolarów, władz kościelnych, zmuszonych wyrazić nie tylko przyzwolenie, ale wręcz aprobatę, i wreszcie władz Peerelu, które musiały przynajmniej zgodzić się na mój udział w zdjęciach na polskiej ziemi. Skoro już mam za sobą ten sukces, pomyślano, że mam szansę przełamać niebywale głębokie uprzedzenie, jakie Max Frisch żywił względem filmowców. Do legendy przeszły jego zmagania $\mathrm{z}$ adaptacjami powieści, do których sprzedawał prawa, ale zawsze z zastrzeżeniem, że musi wyrazić zgodę na ostateczną wersję scenariusza. Tej zgody Frisch nigdy nikomu nie udzielił - w Hollywood leżały różne adaptacje Stillera i Homo Faber, ale po latach stało się dla wszystkich zrozumiałe, że autor bawi się w kotka i myszkę wypuszcza tekst, po czym zakazuje filmowania.

\section{E.C.: Do współpracy nad tekstem Sinobro- dego zaprosiła Pana niemiecka telewizja.}

K.Z.: W latach, o których rozmawiamy, telewizje publiczne poczuwały się jeszcze bardzo mocno do swej kulturalnej misji. Kiedy Frisch wchodził w wiek podeszły i Niemcy, i Szwajcarzy chcieli mieć w swoim dorobku jakąś filmową adaptację jego powieści - nakręcono wprawdzie kilka spektakli telewizyjnych opartych na jego dramatach, ale były to raczej przeniesienia sztuk istniejących autonomicznie na scenie. Ambicją kulturalną publicznych nadawców było złożenie hołdu prozie pisarza w postaci filmu, czyli w formie dla telewizji specyficznej, i stąd narodziła się inicjatywa, w którą niespodziewanie zostałem wciągnięty. Po długiej korespondencji oraz kilku spotkaniach twarzą w twarz udało mi się namówić Frischa na udzielenie zgody na sfilmowanie utworu. Jako „przypieczętowanie” naszej umowy zaproponowałem mu mały epizod - pisarz pojawia się w scenie z Mają Komorowską.
E.C.: Pana adaptacja była bardzo wierna książce. Różni je dosłownie kilka detali jak zmiana narodowości bohaterki, którą grała Maja Komorowska. W filmie stała się ona Polką, podczas gdy w książce była Węgierką.

K.Z.: Frisch sam zaproponował tę zmianę ze względu na Maję Komorowską, którą poznał wcześniej. Gościł on w Polsce w 1980 roku podczas ostatnich przygotowań do prapremiery jego sztuki Tryptyk w Teatrze Współczesnym. Spotkałem się z nim przelotnie. Frisch emocjonował się próbami prowadzonymi przez Erwina Axera, był zachwycony Mają Komorowską, która zagrała główną rolę.

\section{E.C.: Jakie było przyjęcie filmu?}

K.Z.: Film powstał w 1983 roku w dwóch wersjach językowych: niemieckiej i angielskiej. Frisch z ogromną uwagą śledził, jak jego dialog brzmi w języku angielskim. Później zdobyliśmy nagrodę główną w kategorii filmów telewizyjnych w Wenecji. Przed telewizyjną premierą w Zurichu w mieszkaniu Frischa odbył się pokaz dla krytyków literackich, którzy zgodnie orzekli, że powieść należy czytać, a nie oglądać na ekranie - Frisch żartował po ich wyjściu, że właściwie niczego innego nie można się było po nich spodziewać, bo gdyby przyznali wyższość filmowi, to musieliby pozostać bezrobotni.

\section{EC.: W filmie Sinobrody pojawia się Barba- ra Lass, czyli Barbara Kwiatkowska, znana w Polsce z filmów Ewa chce spać (1957) w re- żyserii Tadeusza Chmielewskiego czy Jowita (1967) Janusza Morgernsterna. Barbara Lass pracowała i mieszkała wówczas za granicą.}

KZ.: Chciałem ją na nowo pokazać widzom, była już wówczas trochę zapomniana. Choć była to rola niema, to Barbara Kwiatkowska miała co grać.

EC.: Polski krytyk Jerzy Płażewski, pisząc na początku lat osiemdziesiątych o obec- 
ności polskich filmów za granicą zwracał uwagę na "pułapki telewizji” - zakupy przez zagraniczne stacje telewizyjne praw do emisji filmu. Telewizje wyświetlały filmy na małych ekranach, blokując tym samym ich emisję kinową. Był to m.in. przypadek polskich filmów w RFN: przez osiem lat (1972-1979), mimo nagród na Berlinale, nie zakupiono do dystrybucji kinowej żadnego polskiego filmu. Czy odczuwał Pan tę sytuację także jako problem Pana filmów?

KZ.: Bardzo trudno jest wprowadzić film w Niemczech do dystrybucji kinowej. Ja nie płakałem. Wręcz przeciwnie: cieszyłem się, że chociaż w telewizji obejrzą mój film. Nawet dziś taki film jak Ida ma mikroskopijną publiczność kinową w Niemczech, a gigantyczną we Francji. W tych krajach jest po prostu inna publiczność. W Niemczech Kommunales Kino ledwie przędą, podczas gdy francuska sieć kin studyjnych rozwija się świetnie.

E.C.: $W$ jaki sposób praca $\mathrm{w}$ realiach niemieckich różniła się od pracy $\mathrm{w}$ realiach polskich?

K.Z.: Różnic było bardzo dużo, ale też zmieniały się przez lata. Na początku cała ekipa wykazywała względem mnie sporo nieufności. Zdarzały się próby lekceważenia - co też może wiedzieć reżyser z Polski? Niemcy są jedynym krajem, jaki znam, w którym przewaga językowa jest używana do rozgrywek o władzę. Niemcy to kraj, w którym hierarchia władzy - czyli, potocznie mówiąc, porządek dziobania - jest bardzo akcentowany. Na przykład we Włoszech można żyć zupełnie bez tego. Ludzie znają swoje miejsce i na ogół nie wchodzą nikomu na głowę. W związku z tym nie muszę demonstrować, że jestem szefem. W Niemczech ludzie potrafili powiedzieć przy mnie w trzeciej osobie „ja go nie rozumiem”. Wówczas musiałem przechodzić na angielski czy na francuski i starałem się mówić tak niezrozumiale, że słuchacze znajdowali się kłopocie. Wówczas ja podnosiłem argument, że dana osoba podpisała kontrakt, że będzie znała te języki. Miałem prawo ich wyrzucić, bo wykazałem, że nie posiadają umiejętności, które deklarowali. To były przykre starcia, których stroną był też mój operator. Laboratorium zaczęło bowiem oszukiwać Sławomira Idziaka. Materiał był źle wywoływany. Niemcy się wypierali, w związku $\mathrm{z}$ tym Idziak zrobił sobie w hotelu kontrolne laboratorium, w którym wywoływał te ścinki. Okazało się, że laboratorium robiło nam świadomie na złość, chcieli się go pozbyć. To były męczące walki.

E.C.: Czy istniały różnice w kompetencjach przedstawicieli wybranych zawodów filmowych?

K.Z.: Różnice były niewielkie i łatwo było się w nich zorientować. Trudniejsze do akceptacji były różnice mentalnościowe. Niemcy myśleli inaczej niż my, tego trzeba było się nauczyć.

E.C.: Jak przyjęło Pana niemieckie środowisko filmowe?

K.Z.: Wielu z reżyserów znałem wcześniej. Jak wiadomo, filmowcy nie spotykają się między sobą. Rozmawiamy ze sobą w czasie festiwali. Poza tym sporo pracowałem $\mathrm{w}$ teatrze, a więc miałem kontakt ze środowiskiem teatralnym. Teatr dawał mi schronienie. Nakręciłem sporo dokumentów; niektóre robiłem tylko w pokoju montażowym, jak film Muzyka w warszawskim getcie (1993). Zresztą temat muzyki jest mi bliski, ostatnio zrobiłem dla EBU - European Broadcasting Union - film o klezmerach[1]. Przy tych filmach dla producentów było ważne, aby robił to ktoś trzeci - nie Niemiec, nie Żyd, aby spojrzeć na temat chłodnym okiem.

E.C.: Czy pracując w Niemczech w latach siedemdziesiątych i osiemdziesiątych, spotykał Pan tam innych filmowców z Europy Srodkowo-Wschodniej?

[1] Klezmer in Germany, reż. Caroline Goldie i Krzysztof Zanussi, BBC/WDR, 2007. 
K.Z.: Oczywiście. To ja poznałem Istvána Szabó z moim producentem Manfredem Durniokiem. Durniok zaproponował mu scenariusz, który ja wcześniej odrzuciłem. Nie chciałem realizować tego tematu - to był Mefisto. Uważałem, że mnie jako Polakowi nie wypada się mieszać w rodzinne sprawy Mannów. Szczególnie, że byłem przedstawiony Katii Mann, a do Tomasza Manna mam wielki respekt - uważam go za geniusza. Sama książka była prawnie zakazana w Niemczech jako infamiczna. István nie miał tych dylematów. Wdzięcznie wzruszył ramionami i powiedział: „Przecież to nie jest o Mannach, to jest o mnie". I zrobił z tego świetny film.

\section{E.C.: Czy spotkał Pan za granicą Polaków, Czechów, Słowaków?}

K.Z.: Jiří Menzel się nawet u mnie pojawił w filmie Długa rozmowa $z$ ptakiem - to była z jego strony pomoc koleżeńska. Z filmowców „wędrujących” spotykałem Vojtěcha Jasnýego. Później często kontaktowałem się z László Kováscem. To zwykle były spotkania festiwalowe, nie spotykaliśmy się w pracy.

E.C.: Pana sytuacja była wyjątkowa, ponieważ współpraca $\mathrm{z}$ Niemcami nie była współpracą z przymusu - nie było tak, że nie mógł Pan pracować w Polsce. Czy odczuwał Pan dzięki temu, że znajduje się $\mathrm{w}$ dobrej sytuacji negocjacyjnej?

K.Z.: W Polsce tylko przez moment nie mogłem robić filmów, to było w czasie kręcenia Niedostępnej (Unerrichbare, 1982), która notabene była filmem kinowym - to, niestety, nie wszyscy zaznaczają. Właściwy tytuł filmu to Unapproachable, ponieważ film był nakręcony po angielsku i ku mojej wielkiej radości w Ameryce miał normalną dystrybucję kinową i nawet zebrał jakieś pieniądze.

E.C.: Jak Pan odbierał swoją sytuację w Polsce po doświadczeniach niemieckich? Jak wpłynęły one na Pana pozycję w kraju?
K.Z.: Polska ma taki mechanizm, że cudze chwalicie, swego nie znacie. Jak pochwalą za granicą, w Polsce człowiek od razu wygląda lepiej. Ale było jeszcze coś: dysproporcja materialna. To, że ja mogłem moim zaprzyjaźnionym aktorom zaproponować nawet malutki epizod, było bardzo ważne - wiedziałem, że w Polsce nie zarobią tyle przez rok. Stąd Zapasiewicz zagrał w Imperatywie (Imperativ, 1983), zatrudniałem też Eugeniusza Priwieziencewa. W którymś momencie powiedziano mi, że nie mogę już więcej zatrudniać Polaków. Umówiłem się więc z Tadeuszem Bradeckim, któremu obiecałem rolę, w następujący sposób: jeden $\mathrm{z}$ aktorów niemieckich miał przyjąć zlecenie, a następnie w ostatniej chwili zatelefonować i zwolnić rolę. Bradecki wtedy na własny koszt przyjechał do Zurichu, spotkałem go niby przypadkiem na ulicy i to uratowało sytuację. Priwieziencew po przygodach w Imperatywie, kiedy właściwie nie skończył roli, postanowił wyemigrować. Pociągnął za sobą rodzinę i osiedlił się we Francji, gdzie pracował. Nauczył się francuskiego na tyle dobrze aby grać rosyjskich szpiegów.

\section{E.C.: Polacy pojawiali się w Pana filmach niemieckich i realizowanych w Niemczech zarówno jako aktorzy, jak i pracownicy zawodów filmowych. Pana współpraca z kompozytorem Wojciechem Kilarem była właściwie nienaruszalna.}

K.Z.: Niemcy początkowo byli wobec Kilara bardzo nieufni. Ja się uparłem, że będzie ze mną pracował. W Polsce był znany, ale w Niemczech jego nazwisko nikomu nic nie mówiło. Kilar zorientował się, że oni podejrzewają, że się na niczym nie zna. I natychmiast, z małpią złośliwością, zaczął ich utwierdzać w tych wątpliwościach. Kontrakt już podpisany a ja widziałem, że biedni producenci pytają, czy on zna nuty. I on oczywiście nie odpowiadał jak powinien, że zna, ale zaczyna specjalnie kręcić i pytać, o jakie nuty chodzi, czy te wysokie, czy niskie. Wspaniale się wygłupiał, a oni wpadali w dygot. Potem przełamał to w bardzo śmieszny i elegancki sposób: zaproponował, że zaprezentuje próbkę swojej 
muzyki. Usiadł i zaimprowizował coś, co było parodią tego, co on kiedyś sam pisał. To była parodia skrajnie awangardystycznej muzyki, z której on już się wtedy kompletnie wycofał. Do tego wymyślił słowa, które śpiewał: „Ich suche meine Seele” - „szukam mojej duszy”. To było kompletne kretyństwo, ale oni padli na kolana, bo im to przypomniało brzdąkania Arnolda Schönberga. Potem zrobiłem do tego aluzję w filmie Dotknięcie ręki, gdzie stary kompozytor wykpiwa tych swoich awangardyzujących kolegów.

E.C.: Chciałam na moment powrócić do Manfreda Durnioka. Jest to postać szczególna dla Pana, ale i dla całej kinematografii polskiej. Bez niego proces umiędzynarodowienia polskiego kina nie byłby tak dynamiczny. Durniok kontakty w Polsce nawiązał dzięki Panu.

K.Z.: Durniok był aktywnym producentem i miał duży urok osobisty. Miał świetne otwarcie na Polskę, a potem świetne otwarcie na Chiny. On był człowiekiem, który wciągnął Niemców w chińskie sprawy. Niestety, nagle młodo umarł, a myślę, że byłby dalej bardzo ważną postacią.

E.C.: Manfred Durniok był człowiekiem, który umożliwił Pana amerykańską przygodę - realizację filmu Morderstwo w Catamount.

K.Z.: Zgadza się. Przy okazji chciałbym zwrócić uwagę na przekłamania w czołówce. Ten film wyglądał inaczej niż się go sprzedaje. Dla Niemców był niemiecką produkcją telewizyjną zrobioną w Ameryce, a w Ameryce był inny producent, który o Niemcach nie chciał nawet słyszeć i zrobił to jako swój film, amerykański. Na dwóch terytoriach był rozpatrywany inaczej. W każdym razie był to kinowy film, który nawet w Europie krążył w kinach. Nie uważam go za bardzo dobry film.

E.C.: Ten film broni się po latach, myślę, że Pan go nie docenia. Aktorstwo jest ekspresyjne, ale przekonujące.
K.Z.: Za tym filmem stał potężny producent, Otto Preminger. Nie mógł on ujawnić swojego nazwiska, ponieważ był to film zrobiony „non-union”, poza związkami zawodowymi. Miałem do czynienia z tym człowiekiem-potworem, który notabene jako niemiecki Żyd swobodniej mówił po niemiecku niż po angielsku.

\section{E.C.: Film Morderstwo $w$ Catamount w Polsce dystrybuowany był na początku lat dziewięćdziesiątych przez Polską Fe- derację Dyskusyjnych Klubów Filmowych. Epizodyczną rolę pracownika stacji ben- zynowej zagrał tam Aleksander Bardini. We wspomnieniach dotyczących tego fil- mu napomyka on, że na planie wiele osób z ekipy wykonywało pracę poniżej swoich kwalifikacji - operator Witold Sobociński sam musiał ustawiać reflektory, były też kłopoty $\mathrm{z}$ wypłatą wynagrodzenia.}

K.Z.: Sobociński był bardzo ambitny a ekipa rzeczywiście była średnia. Co do kłopotów z wypłatą gaż - wówczas dowiedzieliśmy się, że w Ameryce jest to częsta niedogodność, szczególnie jeśli pracuje się bez związków zawodowych.

E.C.: Aleksander Bardini w jedynym z wywiadów powiedział, że „[...] należy odróżnić Zanussiego, który realizował filmy wyłącznie w kraju, od Zanussiego pracującego za granicą. Te różnice są widoczne, ale próba ich dokładnego określenia przerasta zarówno ramy tej rozmowy, jak i moje umiejętności diagnozowania”. Czy jako reżyser za granicą jest Pan inną osobą niż w kraju?

K.Z.: Czuję się zupełnie tym samym reżyserem w Polsce, jak i poza jej granicami. Ale nie moge tego udowodnić. Bardini miał rację - poza granicami kraju, a szczególnie podczas pracy nad tym filmem, starałem się wyglądać podobnie do lokalnych twórców. Tam pozowałem na amerykańskiego reżysera. Inaczej bym ich jeszcze bardziej wystraszył. 
184 VARIA

E.C.: Czy pracując w Niemczech, stosował Pan podobną strategię kamuflażu?

K.Z.: Starałem się przystosować do tego, jaki język panował na planie. Oczywiście nie w sensie języka słownikowego, tylko pewnego kodu porozumiewania. Musiałem się zgadzać na wiele rzeczy i udawać, że jestem taki sam jak wszyscy Niemcy. W Niemczech jest bardzo ograniczona demokracja w ekipie. Ludzie się ściśle trzymają swojego zakresu kompetencji i pilnują miejsca w drabinie społecznej. A mnie bawiło zjeść obiad z szoferem zamiast z moją aktorką. Oni uważali to za dziwactwo, dla takich zachowań zawsze musiałem znaleźć solidne uzasadnienie.

E.C.: Dziś Pana „niemieckie” filmy są trudno dostępne, nie ma ich na DVD, w Telewizji Polskiej w latach dziewięćdziesiątych pojawiły się pojedyncze emisje. Prawami do nich dysponują niemieccy producenci. Jaki użytek robią $\mathrm{z}$ tych praw?
K.Z.: Żałuję, że polscy widzowie zostali tych filmów w pewnym sensie pozbawieni. Gdybym miał możliwość przypomnienia jednego tytułu - byłyby to Drogi pośród nocy zrealizowane w 1979 roku dla telewizji WDR, ze zdjęciami Witolda Sobocińskiego i muzyką Wojciecha Kilara. Obsada aktorska była mieszana: w roli Niemca Friedricha wystąpił Mathieu Carriere, jako Elżbieta partnerowała mu Polka Maja Komorowska, Horst Frank zagrał Hansa Alberta, a w roli włosko-żydowskiego bibliotekarza Amadei pojawił się Zbigniew Zapasiewicz. Mam wrażenie, że ten film mi się szczególnie udał. Rekonstrukcję cyfrową w ostatnich latach przeszedł Rok spokojnego słońca (1984), można go obejrzeć na kanale YouTube studia filmowego TOR.

Rozmowa przeprowadzona 3 kwietnia 2017 $w$ siedzibie Studia Filmowego TOR $w$ Warszawie 